\title{
Roka (Eruca vesicaria) yetiştiriciliğinde spektral yansıma ile bitki besin maddesi konsantrasyonu arasındaki ilişkinin belirlenmesi
}

\section{Determination of the relationship between plant nutrient concentration and spectral reflection in Rocket (Eruca vesicaria) cultivation}

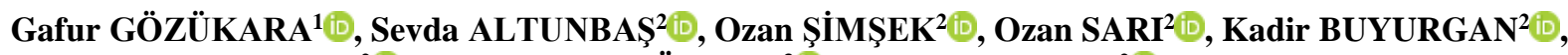

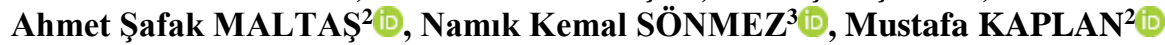

${ }^{1}$ Eskișehir Osmangazi Üniversitesi, Ziraat Fakültesi, Toprak Bilimi ve Bitki Besleme Bölümü, Eskișehir

${ }^{2}$ Akdeniz Üniversitesi, Ziraat Fakültesi, Toprak Bilimi ve Bitki Besleme Bölümü, Antalya

${ }^{3}$ Akdeniz Üniversitesi, Fen Fakültesi, Uzay Bilimleri ve Teknolojileri Bölümü, Antalya

Sorumlu yazar (Corresponding author): G. Gözükara, e-posta (e-mail): ggozukara@ ogu.edu.tr

Yazar(lar) e-posta (Authore-mail): saltunbas@akdeniz.edu.tr, oznsimsek@hotmail.com,ozan_sari@windowslive.com,kadirbuyurgan@hotmial.com, ahmetsafak@akdeniz.edu.tr, nksonmez@akdeniz.edu.tr, mkaplan@akdeniz.edu.tr

\section{MAKALE BILLGISİ}

Alınıs tarihi 12 Mart 2019

Düzeltilme tarihi 19 Nisan 2019

Kabul tarihi 26 Nisan 2019

\section{Anahtar Kelimeler:}

Roka

Spektral yansima

Bitki besin elementi konsantrasyonu

\begin{abstract}
ÖZ
Bitkilerin spektral yansıma karakteristikleri bitki besin maddesi konsantrasyonları ve diğer faktörlerin etkisi ile vejetasyon periyodu boyunca farklılık göstermektedir. Bu çalı̧̧manın amacı, roka (Eruca sativa L.) bitkisinin olgunluk ve hasat dönemlerinde spektral yansıması (RF) ile besin maddesi konsantrasyonu arasındaki ilişkiyi incelemektir. Çalışma kontrollü sera ortamında tesadüf parselleri deneme desenine göre yürütülmüştür. Denemede bitki yetişme periyodu süresince roka bitkisinin bitki besin maddesi konsantrasyonunda varyasyon oluşturmak amacıyla tabandan kat1 organik gübre $\left(0,300\right.$ ve $\left.600 \mathrm{~kg} \mathrm{da}^{-1}\right)$ ve damlamadan siv1 organik gübre $\left(20\right.$ ve $\left.40 \mathrm{lt} \mathrm{da}^{-1}\right)$ uygulanmıştır. Ayrıca olgunluk ve hasat dönemlerinde elektromanyetik spektrumun (EMS) 330$1075 \mathrm{~nm}$ dalga boyu aralı̆̆ında el spektroradyometresi ile bitki probu kullanılarak spektroradyometrik ölçümler gerçekleștirilmiștir. Aynı zamanda spektral yansıma alınan yaprak örneklerinde bitki besin elementi konsantrasyonların belirlemek amacıyla kimyasal analizler yapılmıştır. Araş̦tırma sonuçlarına göre, roka bitkisinin olgunluk döneminde; EMS'un mavi bandı ile bakır $(\mathrm{Cu})\left(0.621^{* *}\right)$, kırmızı bandı ile potasyum $(\mathrm{K})\left(0.554^{* *}\right)$ hasat döneminde ise; yeșil bandı ile fosfor ( $\mathrm{P})\left(0.559^{* *}\right)$, kırmızı bandı ile kalsiyum (Ca) $\left(-0.581^{* *}\right)$ arasında $\mathrm{P} \leq 0.01$ seviyesinde istatistiksel olarak önemli ilişkiler bulunmuştur. Araş̧ırma sonuçları, roka bitkisinin bitki besin maddesi konsantrasyonun tahmin edilmesinde olgunluk dönemine göre hasat döneminde daha yüksek korelasyon olduğunu göstermiștir. Bu sonuçlar ile birlikte özelikle kıșın sera koșullarında roka yetiştiriciliğinde verimi ve kaliteyi etkileyen bazı önemli bitki besin elementi konsantrasyonlarını tahmin edilmesinde bitkiye zarar vermeden hızl, ekonomik ve güvenilir sonuçlar elde edilmiştir.
\end{abstract}

\section{ARTICLE INFO}

Received 12 March 2019

Received in revised form 19 April 2019 Accepted 26 April 2019

\section{Keywords:}

Rocket

Spectral reflectance

Plant nutrients concentration

\begin{abstract}
The spectral reflection characteristics of the plants vary during the vegetation period with the effect of plant nutrient concentrations and other factors. The aim of this study was to investigate the relationship between nutrient concentration and spectral reflection (RF) in the maturity and harvest periods of the rocket (Eruca sativa L.) plant. The study was conducted using a completely randomized block design with three replications under controlled greenhouse conditions. The treatments were solid fertilizers applied before planting at two different rates $(0,300$ and 600 $\left.\mathrm{kg} \mathrm{da}^{-1}\right)$, and liquid organic fertilizer applied by drip (20-40 lt da- $\left.{ }^{1}\right)$ throughout the growing period. Within this period, spectroradiometric measurements were taken with a hand spectroradiometer (plant probe and leaf clips) in the range of 330-1075 $\mathrm{nm}$ wavelength of the electromagnetic spectrum. In the study, leaf samples were taken simultaneously with spectroradiometric measurements and plant nutrient analyzes were performed in these samples. According to the results, at the maturity stage; between blue band and $\mathrm{Cu}\left(0.621^{* *}\right)$, red band and potassium $\mathrm{K}\left(0.554^{* *}\right)$, harvest stage; green band and $\mathrm{P}\left(0.559^{* *}\right)$, red band and $\mathrm{C}\left(-0.581^{* *}\right)$ there was a statistically significant relationship at $\mathrm{P} \leq 0.01$ level. With these results, fast, economical and reliable results were obtained in the estimation of some important plant nutrient concentrations affecting yield and quality in rocket cultivation especially in winter in greenhouse conditions without damaging the plant.
\end{abstract}




\section{Giriş}

Anavatanı Akdeniz bölgesi olarak kabul edilen roka (Eruca sativa L.) yaprakları tüketilen bir sebzedir (Vural ve ark. 2000). Roka bitkisinin Türkiye ölçeğinde 10.38 bin dekar üretim alanıyla birlikte 12.93 ton üretim miktarı bulunmaktadır. Roka yetiştiriciliğinde toplam üretim alanının $\% 2.55$, üretim miktarının ise \%1.69'u Antalya ilinde yapılmaktadır (Anonim 2018). Roka (Eruca sativa L.) gibi yaprağ1 yenen sebzelerde verimi arttırmak ve tüketicinin tercih ettiği koyu yeşil yaprak rengini kısa zamanda sağlayabilmek için yoğun gübreleme yapılmaktadır. Halbuki üretim alanlarında toprak verimliliğini korumak, verim, kalite ve karlılık dengesini koruyabilmek için kullanılacak gübrelerin kaynağının, kullanım dozunun ve zamanının iyi belirlenmesi gerekir (Gözükara ve ark. 2014; Gözükara ve ark. 2016; Kalkan ve ark. 2017). Göz önünde bulundurulması gereken bu faktörler üretim periyodu 1-1.5 ay olan roka bitkisinin yetiştiriciliğinde ise büyük önem taşımaktadır.

Spektral yansıma ve bitki besin maddesi konsantrasyonları bitkilerde yetişme periyodu boyunca farklılık göstermektedir (Sonmez ve ark. 2008b; Altunbas ve ark. 2018a; Altunbas ve ark. 2018b). Geleneksel besin maddesi analiz metotlar yaprakların tahrip edilmesine neden olur. Bu nedenle tek bir yaprakta zamansal olarak besin elementi konsantrasyonlarının değişimini izlemek imkansızdır. Aynı zamanda, bu analiz yöntemleri zaman alıcı ve pahalıdır (Başayiğit ve ark. 2015). Buna karşılık, spektral yansıma (RF) ölçümleri bitkiyi tahrip etmeden, hızlı ve mekansal ölçekte pratik bir şekilde uygulanabilmektedir (Gamon ve Qiu 1999; Cao ve Zhan 2014; Başayiğit ve ark. 2015; Altunbas ve ark. 2018a; Altunbas ve ark. 2018b). Diğer bir ifade ile uzaktan algılama teknikleri yapraklara herhangi bir zarar vermeden bitki besin maddesi konsantrasyonları ve stres faktörlerinin değerlendirmesinde ve izlenmesinde yaygın olarak kullanılmaktadır (Richardson ve ark. 2002; Gitelsan ve ark. 2003; Sar1 ve ark. 2005a; Sar1 ve ark. 2005b; Sonmez ve ark. 2008a; Sonmez ve ark. 2008b; Peng ve Gitelsan 2011; Albayrak ve ark. 2011; Sonmez ve ark. 2015; Zhao ve ark. 2017; Altunbas ve ark. 2018a; Altunbas ve ark. 2018b). Bitki yapraklarında bulunan besin maddesi içeriğinin az olması fotosentezi ve dolayısıyla bitki verim ve kalitesini sınırlandırarak stres koşulları oluşturmaktadır. Bitki besin elementi stresi, özellikle bitki fizyologları tarafindan uzun zamandır araştırılan, abiyotik stres faktörlerinden birisidir. Bu ve bunun benzeri stres koşulları, mineral maddenin eksikliği veya fazlalığı durumunda ortaya çıkabilmektedir (Abadia ve ark. 2011).

Buraya kadar yapılan açıklamalardan ve tespitlerden de anlaşılacağı üzere pek çok araştırmacı bitki besin maddesi konsantrasyonunun dönemlik veya üretim sezonu boyunca spektral yansıma ile tahmin edilmesine ilgi duymuşlar ve bu konu üzerinde ayrıntılı çalışma yapma ihtiyacını hissetmişlerdir. Söz konusu bu araştırma ihtiyacının, bitki besin maddesi içeriği ile spektral yansıma arasında tam olarak kesinleşmiş bilgilerin hala yeterli düzeye ulaşamamış olmasından kaynaklandığ açıktır. Bu çalışmanın amacı roka (Eruca sativa L.) bitkisinin elektromanyetik spekturumun (EMS) görülebilir yakın infrared (VNIR) bölgesindeki spektral yansıması (RF) ile olgunluk ve hasat dönemlerindeki besin maddesi konsantrasyonların tahmin edilebilirliği arasındaki ilişkiyi inceleyerek bitki besin maddesi konsantrasyonu ve spektral yansıma arasındaki ilişkinin açıklanmasına katkı sağlamaktır.

\section{Materyal ve Yöntem}

Türkiye'nin Akdeniz Bölgesi'nde yer alan Antalya ilinde örtü alt1 roka yetiştiriciliğinde tercih edilen Roka Bengi F1 (Küçük Çiftlik Tohumculuk) materyal olarak kullanılmıştır. Deneme $36^{\circ} 53^{\prime} 54.60^{\prime \prime} \mathrm{K}$ ve $30^{\circ} 38^{\prime} 16.99^{\prime \prime} \mathrm{D}$ koordinatlarında ve $32 \mathrm{~m}$ deniz seviyesinden yükseklikte yer alan kontrollü topraklı sera ortamında yürütülmüştür (Şekil 1). Araştırma, kontrollü topraklı sera koşullarında tesadüf parselleri deneme desenine göre 3 tekerrür ve 7 farklı uygulama (Çizelge 1) ile 21 parselde yürütülmüştür. Her bir parsele 32 adet roka bitkisi bulunmaktadır. Tohumların ekilmesi ve hasat için geçen üretim süresi 45 gün olarak planlanmıştır. Çalışma aşamaları; organik gübre uygulamaları, spektral ölçümler ve laboratuvar analizlerinden oluşmaktadır.

Çizelge 1. Katı ve sıvı organik gübre uygulamaları.

Table 1. Solid and liqued organic fertilizer treatments.

\begin{tabular}{cccccccc}
\hline & $\mathbf{K}_{\mathbf{0}}$ & $\mathbf{U}_{\mathbf{1}}$ & $\mathbf{U}_{\mathbf{2}}$ & $\mathbf{U}_{\mathbf{3}}$ & $\mathbf{U}_{\mathbf{4}}$ & $\mathbf{U}_{\mathbf{5}}$ & $\mathbf{U}_{\mathbf{6}}$ \\
\hline Kat1 Organik Gübre $\left(\mathrm{kg} \mathrm{da}^{-1}\right)$ & 0 & 0 & 300 & 600 & 0 & 300 & 600 \\
Siv1 Organik Gübre $\left(1 . \mathrm{da}^{-1}\right)$ & 0 & 20 & 40 & 20 & 40 & 20 & 40 \\
\hline
\end{tabular}

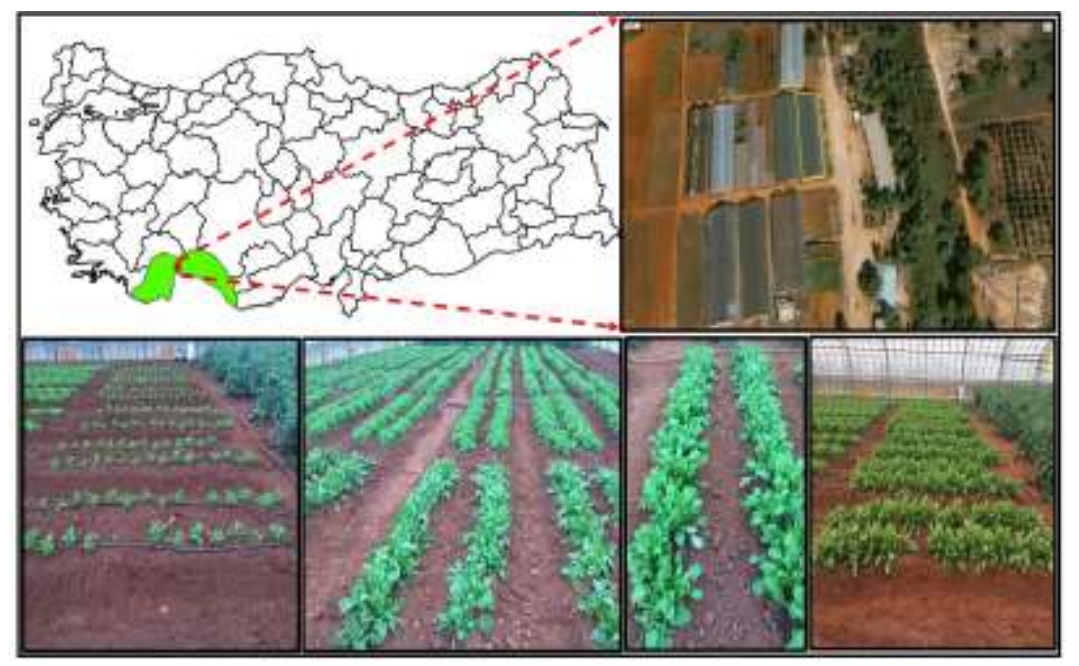

Şekil 1. Çalışma alanı.

Figure 1. Study area. 


\subsection{Katt-sıvı organik gübre uygulamaları}

Katı organik gübreler dikimden önce uygulama dozu kadar parsellere homojen olarak tek seferde uygulanmıştır. Sıv1 organik gübreler ise üretim periyodu boyunca parsellere 10 farklı seferde uygulanmıştır. Çizelge 2 'de denemede uygulanan katı ve sıvı organik gübrelerin bazı özellikleri verilmiştir.

Çizelge 2. Katı ve sıvı organik gübrelerin bazı kimyasal özellikleri.

Table 2. The chemical properties of solid and liquid organic fertilizers.

\begin{tabular}{lcc}
\hline \multicolumn{1}{c}{ Parametreler } & $\begin{array}{c}\text { Katı Organik } \\
\text { Gübre (Altavita) }\end{array}$ & $\begin{array}{c}\text { Sivı Organik } \\
\text { Gübre (Altaverde) }\end{array}$ \\
\hline Organik Madde (\%) & 50 & 20 \\
Hümik+Fülvik asit (\%) & 40 & 15 \\
Toplam N (\%) & 2 & 3 \\
Toplam P (\%) & 2 & 0.7 \\
Toplam K (\%) & 1 & 5 \\
Kuru madde max (\%) & 80 & 40 \\
pH & $5.5-7.5$ & $6-7$ \\
C/N & $15 / 1$ & $4 / 1$ \\
\hline
\end{tabular}

\subsection{Spektral ölçümler}

Spektroradyometrik ölçümlerde taşınabilir Analytical Spectral Devices (ASD) TM (FieldSpec FR) spektroradyometresi kullanılmıştır. Yapraktan ölçümler Spektrumun 325-1075 nm dalga boyları aralığında bitki probu (plant probe) ve temas probu (kontact probe) ile gerçekleştirilmiştir. Her bir parselde bulunan 10 farklı bitkiden spektral ölçüm yapılarak parsel ortalaması alınmıştır. Spektral ölçümler tohum ekiminin 30. gününde (Olgunluk Dönemi) ve 45. gününde (Hasat Dönemi) gerçekleştirilmiş̧tir. Çalışmada, spektroradyometrik ölçümlerle elde edilen yansıma verilerinin EMS'un mavi (450-500 nm), yeşil (501-570 nm), kırmızı (610$700 \mathrm{~nm}$ ) ve yakın kızı̈ötesi (NIR) (701-1075 nm) dalga boyu aralıklarında ayrı ayrı değerlendirilmiştir.

\subsection{Toprak ve yaprak analizleri}

Toprak örneklerinde pH (Jackson 1967), kireç (CaCO3) (Evliya 1964), elektriksel iletkenlik (Anonim 1988) bünye (Bouyoucos 1955), organik madde (Black 1965), toplam N (Black 1957), alınabilir P (Olsen ve Sommers 1982), ekstrakte edilebilir K, Ca ve Mg (Kacar 1972) ve alınabilir Fe, Zn, Cu ve $\mathrm{Mn}$ analizleri (Lindsay ve Norwell 1978) yapılmıştır. Olgunluk (30.gün) ve hasat (45.gün) dönemlerinde 10 farklı bitkiden spektral yansıma ölçümü yapılan yaprak örnekleri bitki besin maddesi analizlerinde kullanılmıştır. Her bir parselden saf su ile yıkanmış olan yapraklar $65^{\circ} \mathrm{C}$ 'de kurutma dolabında son tartım sabit kalıncaya kadar kurutulmuş ve bitki ögütme değirmeninde öğütülerek analize hazır hale getirilmiştir (Kacar ve İ́nal 2008). Kurutulmuş ve ögütülmüş yaprak örneklerinin $\mathrm{N}$ içeriğ modifiye Kjeldahl metoduna göre ve $\mathrm{P}, \mathrm{K}, \mathrm{Ca}, \mathrm{Mg}, \mathrm{Fe}, \mathrm{Mn}, \mathrm{Zn}$ ve $\mathrm{Cu}$ içerikleri için bitki örnekleri Soltanpour ve Workman (1981) tarafindan bildirildiği şekilde yaş yakılıp ICP-OES (Inductively Coupled Plasma-OES) cihazında okunmuştur (Kacar ve İnal 2008).

\section{4. İstatistik Analizler}

İstatistik analizler için SPSS 22.0 (IBM SPSS statistics 2014) ve korelogram grafikleri için $R$ (Lê ve ark. 2008) paket programları kullanılmıştır.

\section{Bulgular ve Tartışma}

Çalışma alanının topraklarının; pH değeri Kellog (1952)'a göre hafif alkalin, $\mathrm{CaCO}_{3}$ Evliya (1964)'ya göre çok yüksek kireçli, EC Soil Survey Staff (1951)'a göre tuzsuz, organik madde Thun ve ark. (1955)'na göre humusça fakir, N konsantrasyonu Loue (1968)'ye göre iyi, P konsantrasyonu Olsen ve Sommers (1982)'a göre yüksek, K konsantrasyonu Pizer (1967)'a göre çok yüksek, Ca ve Mg konsantrasyonları Loue (1968)'ye göre iyi, Lindsay ve Norvell (1978)'e göre Fe ile $\mathrm{Zn}$ konsantrasyonları iyi, $\mathrm{Mn}$ ile $\mathrm{Cu}$ konsantrasyonları yeterli olarak değerlendirilmiştir (Çizelge 3).

Çizelge 3. Çalışma alanı sera topraklarının bazı fiziksel ve kimyasal özellikleri.

Table 3. Some physical and chemical properties of the study area greenhouse soils.

\begin{tabular}{|c|c|c|}
\hline Özellikler & Değer & Değerlendirme \\
\hline Kum (\%) & 40 & \\
\hline Silt (\%) & 22 & Killi Tin \\
\hline Kil (\%) & 38 & \\
\hline $\operatorname{EC}(1: 2.5)\left(\mathrm{dS} \mathrm{m}^{-1}\right)$ & 0.69 & Tuzsuz \\
\hline $\mathrm{pH}(1: 2.5)$ & 7.54 & Hafif Alkalin \\
\hline Kireç (\%) & 17.40 & Çok Yüksek Kireçli \\
\hline Organik Madde (\%) & 2.05 & Humusça Fakir \\
\hline $\mathrm{N}(\%)$ & 0.12 & İyi \\
\hline $\mathrm{P}(\mathrm{ppm})$ & 170 & Yüksek \\
\hline $\mathrm{K}\left(\right.$ meq $\left.100 \mathrm{~g}^{-1}\right)$ & 1.46 & Çok Yüksek \\
\hline $\mathrm{Ca}\left(\right.$ meq $\left.100 \mathrm{~g}^{-1}\right)$ & 21.30 & İyi \\
\hline $\operatorname{Mg}\left(\right.$ meq $\left.100 \mathrm{~g}^{-1}\right)$ & 3.88 & İyi \\
\hline $\mathrm{Fe}\left(\mathrm{mg} \mathrm{kg}^{-1}\right)$ & 4.68 & İyi \\
\hline $\operatorname{Mn}\left(\mathrm{mg} \mathrm{kg}^{-1}\right)$ & 12.64 & Yeterli \\
\hline $\mathrm{Zn}\left(\mathrm{mg} \mathrm{kg}^{-1}\right)$ & 9.14 & İyi \\
\hline $\mathrm{Cu}\left(\mathrm{mg} \mathrm{kg}^{-1}\right)$ & 7.32 & Yeterli \\
\hline
\end{tabular}

Roka bitkisi yetiştiriciliğinde farklı dozlardaki katı-sıvı organik gübrelemenin bitki besin maddesi konsantrasyonu ile birlikte bitkinin enerji kullanımı üzerine etkisinin ortaya konulabilmesi amacı ile spektrumun mavi, yeşil, kırmızı ve yakın kızılötesi bölgesinde elde edilen yansıma değerleri istatistiksel olarak analiz edilmiştir. Bu kapsamda, roka bitki yapraklarının spektral yansıma değerleri ile bitki besin madde konsantrasyonu en fazla, en az, ortalama ve değişim aralıkları (CV) Çizelge 4'de gösterilmiştir. Bitkinin olgunluk döneminde; organik gübre uygulamalarının oluşturduğu değişim aralığının (CV) en fazla demir (Fe) (\%62.11) ve en az azot (N) (\%9.40) elementlerinde olduğu, benzer şekilde roka bitkisinin hasat döneminde de değişim aralığının en fazla Fe (\%68.06) ve en az N'da (\%21.58) olduğu tespit edilmiştir (Çizelge 4). Bitkilerin stres koşullarının belirlenmesinde en önemli belirleyici dalga boyu aralığının elektromanyetik spektrumun yakın kızıl ötesi bölgesi olduğu pek çok araştırmacı tarafından ifade edilmektedir (Slaton ve ark. 2001; Lennartsson 2003; Leone ve ark. 2007; Lillhonga ve Gelady 2011; Cao ve Zhan 2014; Zhao ve ark. 2017). Roka bitkisinin olgunluk ve hasat dönemlerinde spekrumun yakın kızılötesi (NIR) bölgesinde verdiği tepki incelendiğinde, her iki dönemde yansıma değerinin eşit olduğu (0.91) ortaya çıkmıştır. Fakat NIR bandının olgunluk dönemindeki 1.75 olan CV değerinin hasat döneminde 0.52 'ye düşmüş olması katı-sıv1 organik gübre uygulamalarının uygulamaların bitki üzerindeki koşularını azalttığı şeklinde yorumlanmıştır. $\mathrm{Bu}$ sonuçlar ışığında, hasat dönemindeki tüm parametrelerin ortalama değişimi (CV) (\%29.27) olgunluk dönemindeki ortalama değişimden (\%26.18) daha fazla olduğu 
belirlenmiştir. $\mathrm{Bu}$ sonuç ise uygulanan katı ve sıvı organik gübrelerin tamamının hasat dönemine kadar uygulanmış olması ile birlikte incelenen kriterler arasındaki değişim aralığının artması ile açıklanmaktadır. Mavi, yeşil, kırmızı, NIR ve bitki besin maddesi konsantrasyonu arasindaki korelasyon analiz sonuçları Çizelge 5'de gösterilmiştir.

Bitki besin elementi stresi, araştırmacılar tarafindan uzun zamandır araştırılan önemli abiyotik stres faktörlerinden biridir. $\mathrm{Bu}$ gibi stresler, mineral maddenin eksikliği veya fazlalığ durumunda ortaya çıkabilmektedirler (Abadia ve ark. 2011). Bitkilerde N (Azot), Organik maddenin temel yap1 taşı olduğundan, bitki gelişimi ve kuru madde üretimi açısından birincil besindir. Klorofilin temel yapı taşı olması nedeniyle bitkilerde son derece önemlidir. Nitekim N noksanlığ durumunda klorofil molekülleri dağılır. Bitkilerde karbonhidratprotein dengesi etkilenir. Azot düzeyinde artış ile birlikte şeker ve nişasta sentezlenmesi gerekir. Yüksek $\mathrm{N}$ koşullarında amidlerin birikmesi soncunda tat ve aromada bozulmaların ortaya çıkmasıyla hasat ve olgunluk azalır (Mengel ve Kirkby, 2001; Marschner 2008). Spektrumun klorofil soğurum bölgeleri olarak adlandırılan mavi dalga boyu bölgesinde (Sims ve Gamon, 2002; Sonmez ve ark. 2008a) elde edilen veriler incelendiğinde, bitkinin yapraklarının olgunluk dönemindeki $\mathrm{N}$ içeriği ile mavi dalga boyu bölgesinde $\mathrm{P} \leq 0.05$ düzeyinde $\left(0.439^{*}\right)$ önemli ilişki belirlenmiştir. Roka bitkisinin hasat döneminde yaprakların $\mathrm{N}$ içeri ile bu bölgede $\mathrm{P} \leq 0.05$ düzeyinde $(0.514 *)$ önemli ilişki olduğu belirlenmiştir (Şekil 3). P'nin (fosfor) bitkideki en önemli fonksiyonu ise, enerji transferini gerçekleştiren pirofosfat bağlarını oluşturmaktır. Bu aktif fonksiyonlar ile fotosentezde önemli bir rol oynamaktadırlar (Marschner 2003). Yapılan istatistiksel analizler sonucunda, Hasat döneminde P ile yeşil band arasında $\mathrm{P} \leq 0.05$ düzeyinde $\left(0.559^{*}\right)$ ve NIR band arasinda $(0.542 *)$ ilişki olduğu belirlenmiştir (Şekil 3 ve Çizelge 5). K (potasyum) Protein sentezi aşamasında görev alan nitrat redüktaz enziminin aktivasyonunda mutlak gereklidir (Ebtsam ve ark. 2006). Ayrıca, K'nın özellikle adenozin trifosfat (ATP) sentezinde rol alan enzimlerin aktivasyonunda görev alır. ATP ise bitkilerde diğer birçok kimyasal reaksiyonlar için enerji kaynağı olarak kullanılır. Bitkilerde $\mathrm{K}$ noksan olduğunda fotosentez ve ATP oranı azalır, dolayısıyla ATP' ye bağlı tüm süreçler yavaşlar (Shedeed ve ark. 2011). Olgunluk döneminde, $K$ ile yeşil band arasında $\mathrm{P} \leq 0.05$ düzeyinde $\left(0.489^{*}\right)$ ve kırmızı band ile $\mathrm{P}$ $\leq 0.01$ düzeyinde $\left(0.554^{* *}\right)$ (Şekil 2 ve Çizelge 5$)$ ilişki olduğu belirlenmiştir. Hücre duvarlarında Pektatlar şeklinde bulunan Ca hücre duvarlarının ve bitki dokularının güçlenmesinde temel görev üstlenmiştir (Kacar ve Katkat, 2010). Hasat döneminde, Ca ile sadece Kırmızı band ile $\mathrm{P} \leq 0.05$ düzeyinde $(-0.581 * *)$ arasında kuvvetli ilişsi belirlenmiştir (Şekil 3 ve Çizelge 5). Magnezyum $(\mathrm{Mg})$ fotosentezde klorofil molekülünün merkez atomu olarak görev yapar (Marschner 2008). Dolayısıyla klorofil sentezi için mutlak gereklidir. Hasat döneminde, $\mathrm{Mg}$ ile yeşil bant arasında $\mathrm{P} \leq 0.05$ düzeyinde $(-0.499 *)$ (Şekil 2) ve NIR band $\left(-0.476^{*}\right)$ (Şekil 3) arasında $\mathrm{P} \leq 0.05$ düzeyinde ilişki olduğu belirlenmiştir (Şekil 3, Şekil4 ve Çizelge 5).

Çinko $(\mathrm{Zn})$ elementinin bitkilerde protein ve karbonhidrat metabolizmasında önemli fonksiyonları olduğu ve biyolojik membranların stabilitesi üzerinde de etkinliği söz konusudur

Çizelge 4. Mavi, yeşil, kırmızı ve NIR bandlar ile bitki besin elementi konsantrasyonlarının en yüksek, en az ve ortalama değerleri.

Table 4. Maximum, minimum and mean values of plant nutrient elements concentration.

\begin{tabular}{|c|c|c|c|c|c|c|c|c|c|c|c|c|c|c|}
\hline & $\begin{array}{l}\text { Mavi } \\
\text { Band }\end{array}$ & $\begin{array}{l}\text { Yeşil } \\
\text { Band }\end{array}$ & $\begin{array}{c}\text { Kırmızı } \\
\text { Band }\end{array}$ & $\begin{array}{c}\text { NIR } \\
\text { Band } \\
\end{array}$ & $\begin{array}{l}\mathrm{N} \\
\% \\
\end{array}$ & $\begin{array}{l}\mathrm{P} \\
\% \\
\end{array}$ & $\begin{array}{l}\mathrm{K} \\
\% \\
\end{array}$ & $\begin{array}{l}\mathrm{Ca} \\
\%\end{array}$ & $\begin{array}{c}\mathrm{Mg} \\
\% \\
\end{array}$ & $\begin{array}{c}\mathrm{Zn} \\
\mathrm{ppm}\end{array}$ & $\begin{array}{c}\mathrm{Fe} \\
\mathrm{ppm}\end{array}$ & $\begin{array}{c}\mathrm{Cu} \\
\mathrm{ppm}\end{array}$ & $\begin{array}{c}\mathrm{Mn} \\
\mathrm{ppm}\end{array}$ & Ort. \\
\hline & \multicolumn{14}{|c|}{ Olgunluk Dönemi } \\
\hline $\begin{array}{c}\text { En } \\
\text { fazla }\end{array}$ & 0.057 & 0.165 & 0.085 & 0.932 & 5.64 & 0.36 & 3.73 & 3.48 & 0.26 & 23.96 & 103.41 & 4.10 & 12.25 & \\
\hline En az & 0.052 & 0.145 & 0.068 & 0.876 & 5.11 & 0.26 & 2.80 & 1.79 & 0.19 & 16.34 & 39.18 & 1.85 & 7.36 & \\
\hline Ort. & 0.054 & 0.156 & 0.079 & 0.910 & 5.48 & 0.31 & 3.24 & 2.46 & 0.22 & 18.83 & 61.44 & 3.09 & 9.60 & \\
\hline $\mathrm{CV}$ & 3.55 & 3.26 & 5.49 & 1.75 & 9.40 & 27.78 & 24.93 & 48.56 & 26.92 & 31.80 & 62.11 & 54.88 & 39.92 & 26.18 \\
\hline & \multicolumn{14}{|c|}{ Hasat Dönemi } \\
\hline $\begin{array}{c}\text { En } \\
\text { fazla }\end{array}$ & 0.056 & 0.161 & 0.079 & 0.923 & 6.82 & 0.40 & 3.44 & 2.78 & 0.18 & 17.15 & 155.35 & 2.79 & 23.90 & \\
\hline En az & 0.051 & 0.133 & 0.068 & 0.902 & 5.35 & 0.25 & 2.23 & 1.01 & 0.12 & 11.71 & 49.62 & 1.45 & 16.89 & \\
\hline Ort. & 0.053 & 0.147 & 0.073 & 0.913 & 6.12 & 0.34 & 2.77 & 1.74 & 0.14 & 14.16 & 97.77 & 2.16 & 19.68 & \\
\hline $\mathrm{CV}$ & 3.17 & 4.55 & 3.91 & 0.52 & 21.58 & 37.50 & 35.17 & 63.67 & 33.33 & 31.72 & 68.06 & 48.03 & 29.33 & 29.27 \\
\hline
\end{tabular}

Çizelge 5. Yansıma ve bitki besin elementi konsantrasyonları arasındaki korelasyon katsayıları.

Table 5. The correlation coefficents between reflectance and plant nutrient elements concentration.

\begin{tabular}{|c|c|c|c|c|c|c|c|c|c|}
\hline Bandlar & $\begin{array}{l}\mathrm{N} \\
\%\end{array}$ & $\begin{array}{l}\mathrm{P} \\
\%\end{array}$ & $\begin{array}{l}\mathrm{K} \\
\%\end{array}$ & $\begin{array}{l}\mathrm{Ca} \\
\%\end{array}$ & $\begin{array}{c}\mathrm{Mg} \\
\%\end{array}$ & $\begin{array}{c}\mathrm{Zn} \\
\mathrm{ppm}\end{array}$ & $\begin{array}{c}\mathrm{Fe} \\
\mathrm{ppm}\end{array}$ & $\begin{array}{l}\mathrm{Cu} \\
\mathrm{ppm}\end{array}$ & $\begin{array}{l}\mathrm{Mn} \\
\mathrm{ppm}\end{array}$ \\
\hline \multicolumn{10}{|c|}{ Olgunluk Dönemi } \\
\hline Mavi & $0.439 *$ & 0.199 & 0.343 & 0.123 & 0.130 & -0.304 & -0.177 & $0.621 * *$ & 0.002 \\
\hline Yeşil & 0.007 & -0.405 & $0.489^{*}$ & 0.243 & -0.002 & -0.062 & 0.097 & -0.270 & 0.088 \\
\hline Kırmızı & 0.137 & -0.112 & $0.554 * *$ & 0.143 & 0.207 & -0.075 & 0.124 & 0.414 & 0.266 \\
\hline NIR & -0.211 & -0.292 & 0.124 & -0.281 & 0.177 & 0.259 & 0.393 & -0.272 & $0.483 *$ \\
\hline \multicolumn{10}{|c|}{ Hasat Dönemi } \\
\hline Mavi & $0.514 *$ & 0.214 & -0.015 & 0.250 & 0.123 & 0.328 & 0.050 & 0.011 & -0.135 \\
\hline Yeşil & 0.401 & $0.559^{* * *}$ & -0.314 & -0.389 & $-0.499 *$ & $0.534^{*}$ & $-0.492 *$ & $0.441^{*}$ & -0.162 \\
\hline Kırmızı & 0.225 & 0.172 & -0.125 & $-0.581 * *$ & -0.335 & 0.219 & -0.376 & 0.131 & -0.155 \\
\hline NIR & 0.242 & $0.542 *$ & -0.395 & -0.179 & $-0.476^{*}$ & 0.089 & -0.368 & 0.272 & $-0.512 *$ \\
\hline
\end{tabular}




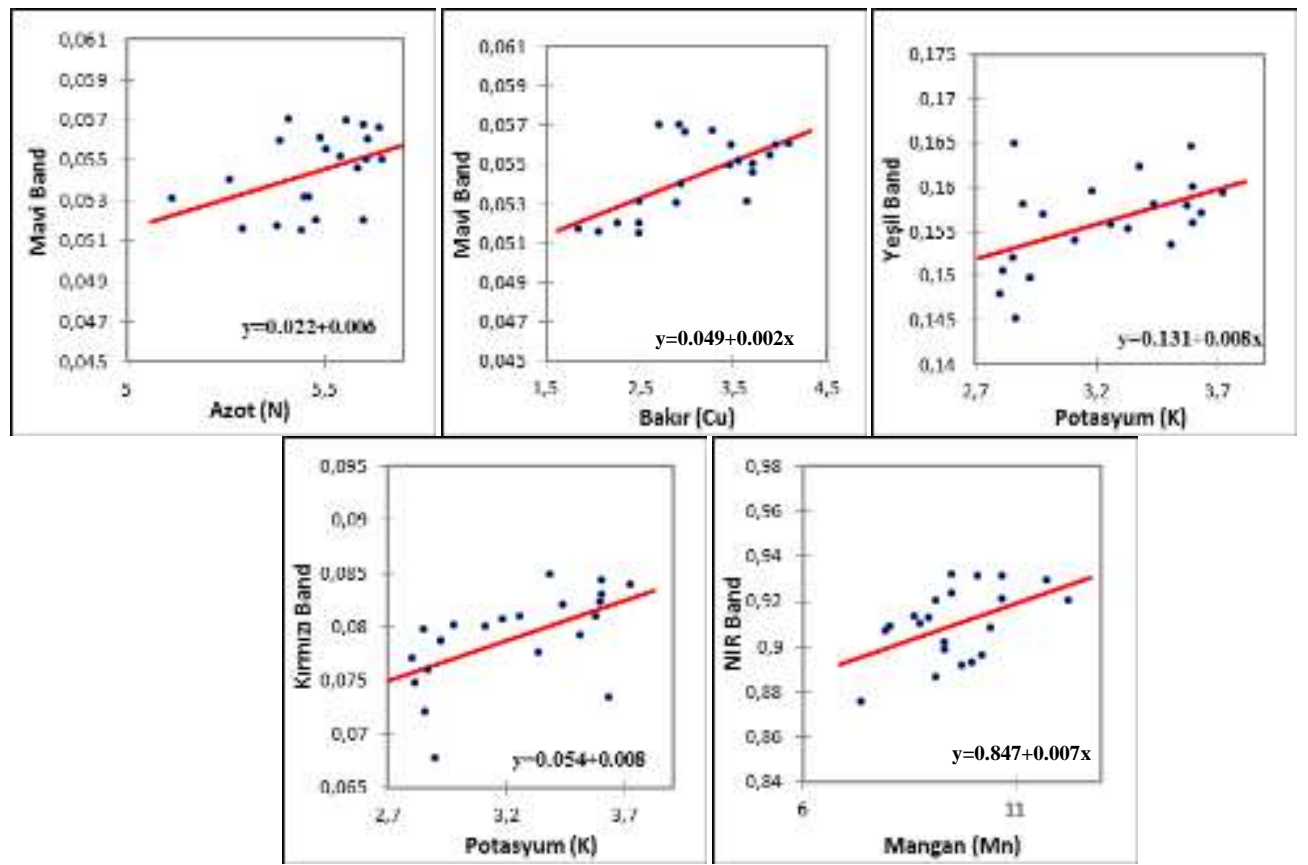

Şekil 2. Olgunluk döneminde spektral yansıma ve bitki besin maddesi konsantrasyonu arasındaki linear regresyon ( $P \geq 0.01$ ve $P \geq 0.05)$. Figure 2. Linear regresyon between spektral reflectance plant nutrition concentration at maturity stage $(P \geq 0.01$ ve $P \geq 0.05)$.

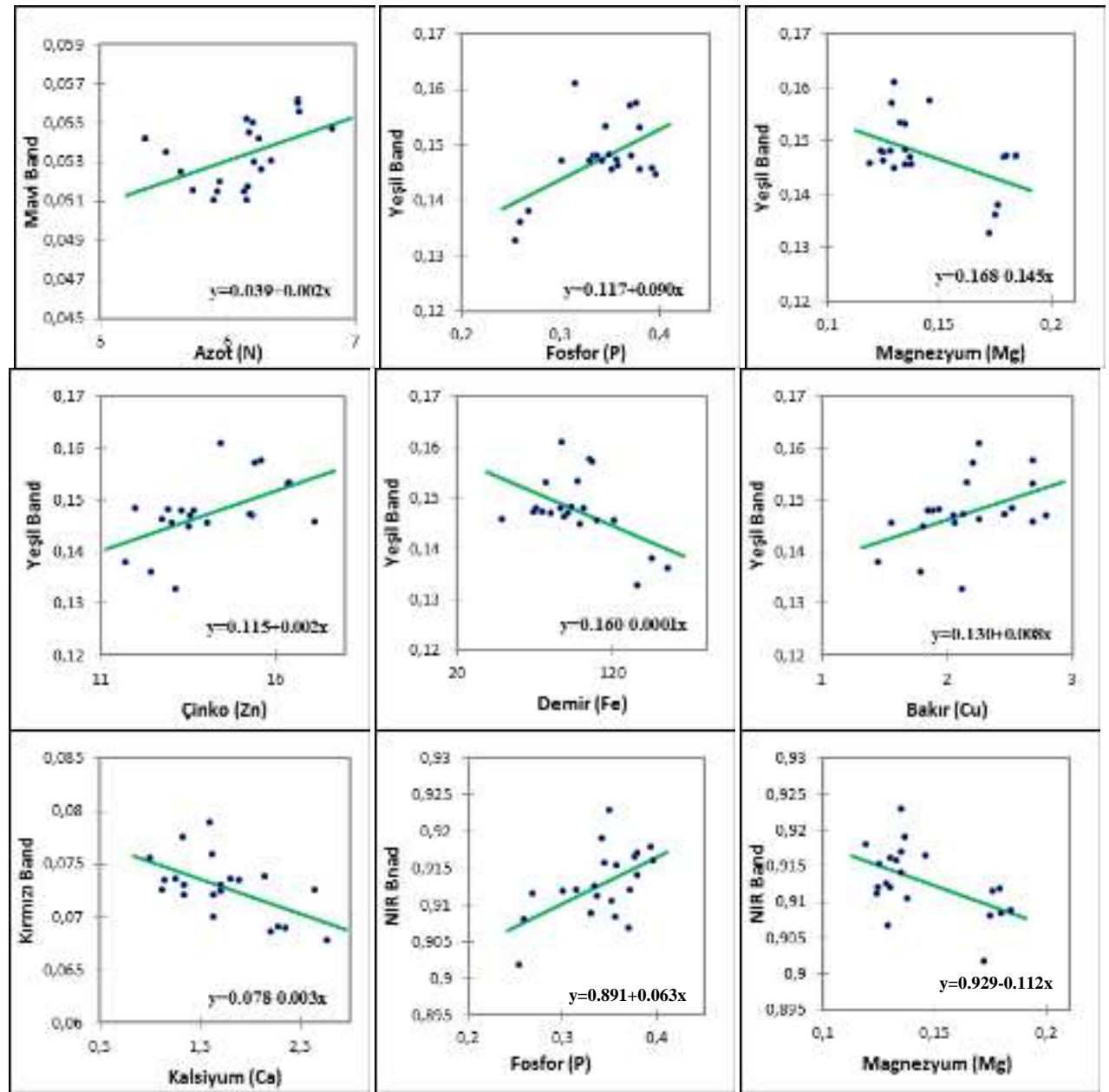

Şekil 3. Hasat döneminde spektral yansıma bitki besin maddesi konsantrasyonu arasındaki linear regresyon $(P \geq 0.01$ ve $P \geq 0.05)$. Figure 3. Linear regresyon between spektral reflectanceplant nutrition concentration at harvest stage $(P \geq 0.01$ ve $P \geq 0.05)$. 


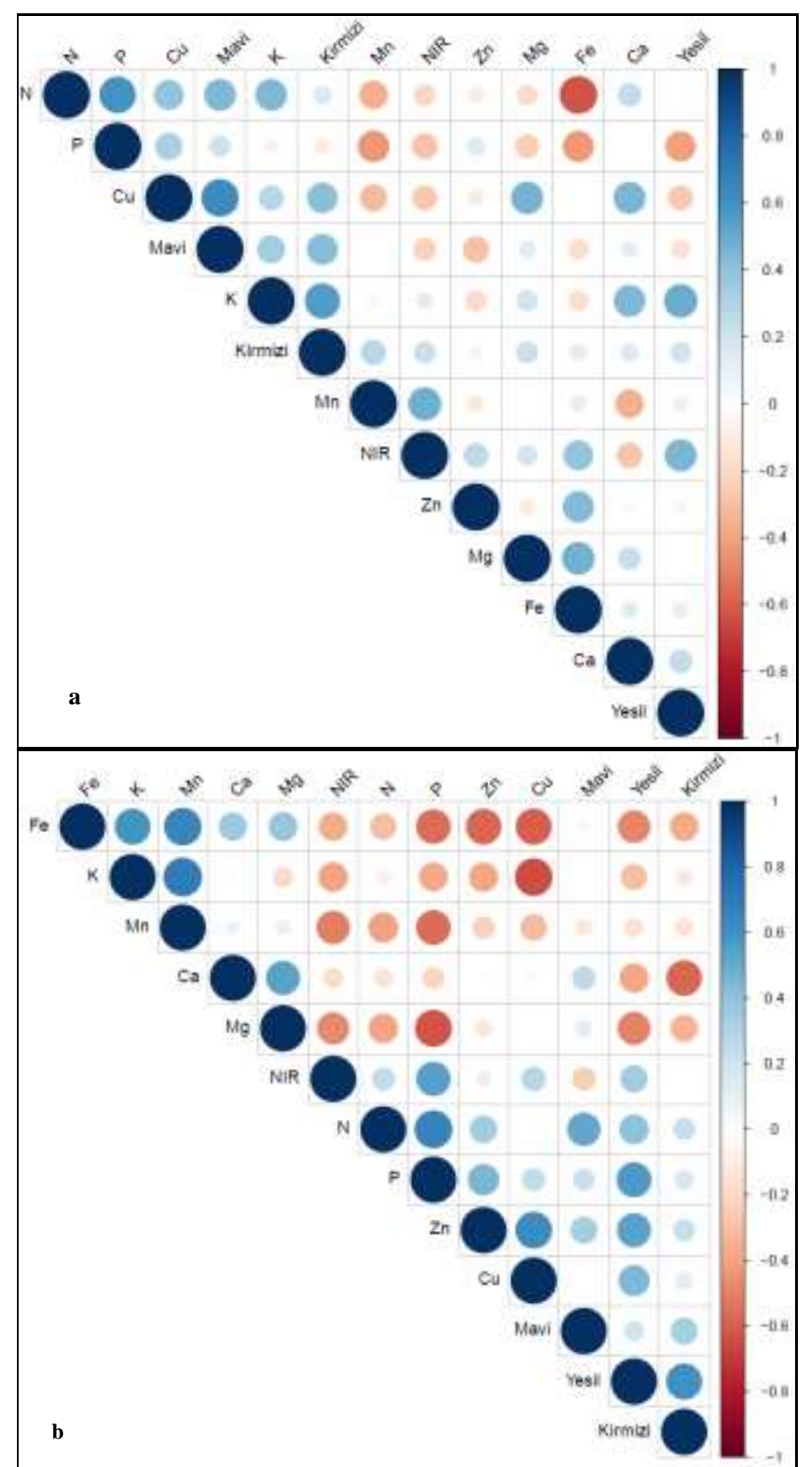

Şekil 4. Olgunluk (a) ve hasat (b) dönemlerinde mavi, yeşil, kırmızı ve NIR bandları ile bitki besin elementlerinin konsantrasyonları arasındaki korelogram.

Figure 4. Correlogram between the concentrations of plant nutrients and blue, green, red and NIR bands at maturity (a) and harvest (b) periods.

(Kacar ve Katkat, 2010). Araștırma ile birlikte, sadece hasat döneminde $\mathrm{Zn}$ içeriği ile yeşil band arasında $\mathrm{P} \leq 0.05$ düzeyinde $(-0.534 *)$ ilişki tespit edilmiştir (Şekil 3 ve Çizelge 5). Çinko noksanlığ durumunda, bitki çeşidine ve noksanlığın derecesine bağlı olarak net fotosentez oranında $\% 50$ ile $\% 70$ oranında azalma meydana gelmektedir. Bitki klorofil içeriği çinko noksanlığında olağanüstü azalmaktadır (Kacar ve Katkat, 2010). Fe (Demir), klorofil sentezinde katalizör olarak görev almaktadır. Elektron alma-verme yeteneği nedeniyle başta fotosentez olmak üzere bitkide meydana gelen sayısız fizyolojik olayda çok önemli rolü vardır. Yükseltgenme ve indirgenme özelliğinden dolayı bitkilerde iyon taşınımında katkı sağlar. Enzimatik (hidrogenez, katalaz, diastaz ve stokromaz) olayları hızlandırarak, bitki bünyesinde oluşan oksidasyon ve redüksiyon olaylarını düzenler. Protein sentezinde görev alması nedeniyle $\mathrm{Fe}$ ' yetersizliğinde mevcut proteinler de tekrar parçalanır ve amino asitler açığa çıkar (Güneş ve ark. 2000; Mengel ve Kirkby 2001; Güzel ve ark. 2002; Marschner 2008). Fe içeriği ile sadece hasat döneminde yeşil bant arasında $\mathrm{P}$ $\leq 0.05$ düzeyinde $(-0.492 *$ ) ilişki tespit edilmiştir (Şekil 3 ve Çizelge 5). Bakır $(\mathrm{Cu})$ klorofil stabilitesi ve sentezinde ayrıca bitkilerde karbonhidrat ve protein metabolizması üzerine etkileri vardır (Marschner 2003). Proteinler ile kompleks oluşturan $\mathrm{Cu}$, çeşitli enzimlerin yapısından yer alır. Cu'nun \%50'den fazlası kloroplastlarda ve plastosiyanine bağlanmış olarak bulunur (Kacar ve Katkat 2010). Cu ile olgunluk döneminde, mavi bant arasında $\mathrm{P} \leq 0.01$ düzeyinde $\left(0.621^{* *}\right)$ ve hasat döneminde, yeşil bant ile $\mathrm{P} \leq 0.05$ düzeyinde $(0.441 *)$ ilişki olduğu belirlenmiştir 
(Çizelge 5). Mn ise fotosentezde elektron aktarımı ve enzim-S ile süperoksit dismutaz (SOD) enzimlerinin yapısında yer almaktadır (Kacar ve Katkat 2010). Özellikle fotosentezde küçük ama önemli görevi olan Mn ile NIR band arasında olgunluk döneminde $\mathrm{P} \leq 0.05$ düzeyinde $\left(0.483^{*}\right)$ (Şekil 2) ve hasat döneminde $(-0.512 *)$ ilişki olduğu belirlenmiştir (Şekil 3 ve Çizelge 5).

\section{Sonuç}

Araştırma sonuçlarına göre; yapraktan elde edilen reflektans ve bazı bitki besin maddesi miktarı arasında istatistiksel olarak $\mathrm{P} \leq 0.01$ ve $\mathrm{P} \leq 0.05$ düzeyinde ilişki olduğu belirlenmiştir. Kat1S1V1 organik gübrelerin incelenen parametreler üzerindeki ortalama değişimlere etkisi hasat döneminde (\%29.27) olgunluk dönemine (\%26.18) göre daha fazla olarak belirlenmiştir. Oluşan bu fark; spektral yansıma ve bitki besin maddesi içeriğinin dönemsel olarak değişiklik göstermesinden kaynaklanmaktadır. Olgunluk döneminde $\mathrm{P} \leq 0.01$ düzeyinde; $\mathrm{K}$ (potasyum) ile kırmızı band $\left(0.554^{* *}\right)$ ve $\mathrm{Cu}$ (bakır) ile mavi band $\left(0.621^{* *}\right)$ arasinda, hasat döneminde ise $\mathrm{P} \leq 0.01$ düzeyinde; P (fosfor) ile yeşil band $\left(0.599^{* *}\right)$ ve Ca (kalsiyum) ile kırmızı band arasında (-0.581**) kuvvetli bir korelasyon olduğu tespit edilmiștir. Bu tespitler, bitkinin olgunluk ve hasat dönemlerindeki $\mathrm{P}, \mathrm{K}, \mathrm{Ca}$ ve $\mathrm{Cu}$ konsantrasyonlarını spektral yansıma ( $\mathrm{P} \leq 0.01$ düzeyinde) ile daha fazla ilişkili olduğunu göstermektedir. Özellikle mikro elementlerin $(\mathrm{Zn}, \mathrm{Fe}$ ve $\mathrm{Cu})$ konsantrasyonlarının hasat döneminde yeşil dalga boyu ile tahmin edilebilme oranının yüksek olduğu belirlenmiştir. Sonuç olarak, olgunluk veya hasat dönemlerinde bitkilerin yapraklarından elde edilen spektral yansıma ile bazı bitki besin maddesi konsantrasyonun tahmin edilmesinde bitkiye zarar vermeden hızlı, ekonomik ve güvenilir sonuçlar elde edildiği belirlenmiştir. Özellikle mavi (450-500 nm), yeşil (501-570 $\mathrm{nm})$, kırmızı (610-700 nm) ve NIR (701-1075 $\mathrm{nm})$ band aralıklarının daraltılarak daha spesifik hale getirilmesi ile yansıma ve bitki besin elementleri arasındaki ilişkinin artabileceği düşünülmektedir.

\section{Kaynaklar}

Abadia J, Vázquez S, Álvarez RR, Jendoubi H, Abadía A, Fernández AA, Millán AFL (2011) Towards a knowledge-based correction of iron chlorosis. Plant Physiology and Biochem 49: 471-482.

Albayrak S, Başayiğit L, Türk M (2011) Use of canopy- and leafreflectance indices for the detection of quality variables of Vicia species. International Journal of Remote Sensing 32: 1199-1211.

Altunbas S, Gozukara G, Sonmez NK, Maltaş AŞ, Kaplan M (2018a) Relationship between spectral reflectance and plant nutrientchlorophyll content in lettuce (Lactuca Sativa L.) growing. Fresenius Environmental Bulletin 27(5A): 3624-3632.

Altunbas S, Sonmez NK, Gozukara G, Maltaş AŞ, Kaplan M (2018b) Relationship between solid-liquid organic fertilization and spectral reflectance in lettuce (Lactuca Sativa L.) growing. Fresenius Environmental Bulletin 27(8): 5355-5362.

Anonim (1988) Meyve, sebze ve mamulleri-nitrit ve nitrat tayinimoleküler absorpsiyon spektrofotometrik metot. Türk Standard1, ICS 67.080, TS 6183/Aralık 1988.

Anonim (2018) T.C. Başbakanlık Türkiye İstatistik Kurumu, TÜİK verileri.

Başayiğit L, Dedeoğlu M, Akgül H (2015) The prediction of iron contents in orchards using VNIR spectroscopy. Turkish Journal of Agriculture and Forestry 39: 123-134.

Black CA (1957) Soil-plant relationships. John Wiley and Sons, Inc., New York.
Black CA (1965) Methods of Soil Analysis. Part 2, Amer. Society of Agronomy Inc., Publisher Madisson, Wilconsin, U.S.A., 13721376.

Bouyoucos GJ (1955) A recalibration of the hydrometer method for making mechanical analysis of the soils. Agronomy Journal 4(9): 434.

Cao H, Zhan Y (2014) Near-infrared spectra quantitative analysis for flue gas of thermal power plant based on wavelength selection. Scientific Research and Essay 9: 288-292.

Ebtsam M, Morsy AA, Mahmoud AA, Khali AA (2006) Influence of bio-inoculation and various potassium application rates on soil fertilitiy, maize productivity and yield components. Egyptian Journal of Applied Sciences 21: 255-267.

Evliya H (1964) Kültür bitkilerinin beslenmesi. Ankara. Üniv. Ziraat Fak. Yayınları, Yayın no: 36, 292-294, Ankara.

Gamon JA, Qiu H (1999) Ecological applications of remote sensing at multiple scales. In: F. I. Pugnaire, \& F. Valladares (Eds.), Handbook of functional plant ecology, New York: Marcel Dekker, pp. 805-846.

Gitelsan AA, Gritz Y, Merzlyak MN (2003) Relationships between leaf chlorophyll content and spectral reflectance and algorithms for nondestructive chlorophyll assessment in higher plant leaves. Journal of Plant Physilogy 160: 271-281.

Gözükara G, Kalkan H, Kaplan M (2014) Evaluation of differences in fertilizer consumption of autumn tomato production in greenhouse. 9 th International soil science congress, Antalya, s. 685-689.

Gözükara G, Kaplan M, Kalkan H (2016) Evaluation of Soil Analysis Results and Fertilizer Consumption in Autumn Greenhouse Tomato Cultivation. 2. International Conference on Science, Ecology and Technology, Barcelona. s. 721-726.

Güneş A, Alpaslan M, İnal A (2000) Bitki besleme ve gübreleme, A.Ü. Ziraat Fakültesi, Yayın No: 1514.

Güzel N, Gülüt KY, Büyük G (2002) Toprak verimliliği ve gübreler. Ç.Ü. Ziraat Fakültesi, Genel Yayın No: 246.

Kalkan H, Gözükara G, Kaplan M (2017) Sera güzlük domates yetiştiriciliğinde yeni eğilim: sıvı organik gübre tüketimi. Academia Journal of Engineering and Applied Sciences 2(3): 92-100.

IBM SPSS Statistics (2014) IBM SPSS statistics software version 22. SPSS Inc., Chicago.

Jackson MC (1967) Soil chemical analysis. Prentice Hall of India Private'Limited, New Delhi.

Kacar B (1972) Bitki ve toprağın kimyasal analizleri. II. Bitki Analizleri, A.Ü. Ziraat Fak. Yayınları: 453, Ankara.

Kacar B, İnal A (2008) Bitki analizleri. Nobel Yayın Dağıtım, Ankara.

Kacar B, Katkat V (2010) Bitki besleme. Nobel yayınları, s. 660, Ankara.

Kellog CE (1952) Our garden soils. The Macmillan Company, Newyork.

Lê S, Josse J, Husson F (2008) FactoMineR: An R Package for Multivariate Analysis. Journal of Statistical Software. 25(1). pp. 118.

Lennartsson M, Ögren E (2003) Predicting the cold hardiness of willow stems using visible and near-infrared spectra and sugar concentrations. Trees-Structure Function 17: 463-470.

Leone AP, Menenti M, Buondonno A, Letizia A, Maffei C, Sorrentino G (2007) A field experiment on spectrometry of crop response to soil salinity. Agricultural Water Management 89: 39-48.

Lillhonga T, Geladi P (2011) Three-way analysis of a designed compost experiment using near-infrared spectroscopy and laboratory measurements. Journals of Chemometrics 25: 193-200.

Lindsay WL, Norvell WA (1978) Development of a DTPA soil test for Zinc, Iron, Manganese and Copper. Soil Science American Journal 42(3): 421-428. 
Loue A (1968) Diagnostic petiolaire de prospection etudes sur la nutrition et al. fertilisation potassiques de la vigne. Societe Commerciale des Potasses d' Alsace Services Agronomiques 3141.

Marschner H (2003) Mineral nutrition of higher plants, Academic Press, London.

Marschner H (2008) Mineral nutrition of higher plants, Academic Press, Digital Print. Academic Press., pp. 889.

Mengel K, Kirkby EA (2001) Principles of plant nutrition. 5th Edition. Kluwer Academic Publishers. ISBN: 1-4020-0008-1, Dordrecht, The Netherlands.

Olsen SR, Sommers EL (1982) Phosphorus soluble in sodium bicarbonate, methods of soil analysis, Part 2, Chemical and Microbiological Properties. Edit: A.L. Page, P.H. Miller, D.R. Keeney, pp. 404-430.

Peng Y, Gitelson AA (2011) Application of chlorophyll-related vegetation indices for remote estimation of maize productivity. Agriculturel and Forest Meteorlogy 151: 1267-1276.

Pizer NH (1967) Some advisory aspect soil potassium and magnesium. Tech. Bull No: 14-184.

Richardson AD, Duigan SP, Berlyn GP (2002) An evaluation of noninvasive methods to estimate foliar chlorophyll content. New Phytol 153: 185-194.

Sari M, Sonmez NK, Karaca M (2005a) Relationship between chlorophyll content and canopy reflectance in washington navel orange trees (citrus sinensis (L.) osbeck). Pakistan Journal of Botany 37(4): 1093-1102.

Sari M, Sonmez NK, Kurklu A (2005b) Determination of seasonal variation of solar energy utilization by the leaves of washington navel orange trees (Citrus sinensis L. Osbeck). International Journal of Remote Sensing 26: 3295-3307.

Sims DA, Gamon JA (2002) Relationships between leaf pigment content and spectral reflectance across a wide range of species, leaf structures and developmental stages. Remote Sensing of Environment 8: 337-354.
Slaton MR, Hunt ER, Smith WK (2001) Estimating near infrared leaf reflectance from leaf structural characteristics. American Journal of Botany 88(2): 278-284

Shedeed SI, Nasef MA, Abo-Basha DM (2011) A comparative study on responce of lettuce plants to different K-fertilizer sources through applying fertigation system. Research Journal of Agriculture and Biological Sciences 7(1): 68-78.

Soil Survey Staff (1951) Soil survey manuel. Agricultural Research Administration, U.S Depth. Agriculture, Handbook No: 18.

Soltanpour PN, Workman SM (1981) Use of inductively-coupled plasma spectroscopy for the simultaneous determination of macro and micro nutrients in NH4HCO3-DTPA extracts of soils. In Barnes R.M. (ed). Developments in Atomic Plasma Analysis, USA, pp. 673-680.

Sonmez NK, Emekli Y, Sari M, Bastug R (2008a) Relationship between spectral reflectance and water stress conditions of Bermuda grass (Cynodon dactylon L.). New Zealand Journal of Agriculturel Research 51: 223-233.

Sonmez NK, Sari M, Sonmez S (2008b) Relations mineral content and canopy reflectance in Washington navel orange trees. Asian Journal of Chemistry 20(6): 4760-4772.

Sonmez NK, Aslan GE, Kurunc A (2015) Relationship spectral reflectance under different salt stress conditions of tomato. Jorunal of Agriculturel Sciences 21: 585-595.

Thun R, Hermann R, Knıckman E (1955) Die untersuchung von boden neuman verlag, Radelbeul und Berlin, s. 48-48.

Vural H, Eşiyok D, Duman İ (2000) Kültür Sebzeleri (Sebze Yetiştirme). Ege Üniversitesi Ziraat Fakültesi Bahçe Bitkileri Bölümü, Bornova, İzmir, s. 440.

Zhao X, Hui B, Hu L, Cheng Q, Via BK, Nadel R, Starkey T, Enebak S (2017) Potential of near infrared spectroscopy to monitor variations insoluble sugars in Loblolly pine seedlings after cold acclimation. Agricultural and Forest Meteorology 232: 536-542. 